\title{
Ewa Goczał
}

\section{Na kształt krzyża. Doloryzm Aleksandra Wata w świetle De imitatione Christi}

\section{In the Shape of the Cross. The Dolorism of Aleksander Wat in the Light of De imitatione Christi}

Potem na pustyni ilijskiej jedyną moją książką

Była oprawna w czarną ceratę [-] Naśladowanie Jezusa Chrystusa Ktoś mądry z Londynu przesłał ją uchodźcom, przechowuję Ją dotąd, przez wszystkie dni mojej tułaczki ${ }^{1}$.

Najlepszy środek na ból - powiedział wiceminister W... cierpiącemu X...

- to najskuteczniejszy środek na pluskwy: polubić! ${ }^{2}$

1 Aleksander Wat, Coś niecoś o „Piecyku” [wersja brulionowa], w idem, Notatniki, oprac. Adam Dziadek, Jan Zieliński, (Katowice: Instytut Badań Literackich PAN, 2015), 821.

2 Aleksander Wat, Moralia, w idem, Dziennik bez samogłosek (Warszawa: Czytelnik, 1990), 31. 


\section{Abstrakt}

Celem artykułu jest refleksja nad wybranymi utworami Aleksandra Wata umieszczonymi w kontekście De imitatione Christi Tomasza à Kempis oraz zweryfikowanie poglądu, że cierpienie funkcjonuje w świadomości i wyobraźni poetyckiej pisarza jako wartość sprzyjająca duchowemu rozwojowi jednostki. Autorka analizuje wspomnienia poety, aby pokazać, w jaki sposób lektura tekstu odkrytego przez niego w czasie wojny, na zsyłce w Kazachstanie, wpłynęła na wybory i postawy Wata lub też jego postrzeganie podjętych przez siebie decyzji (przede wszystkim tej o odmowie przyjęcia radzieckiego obywatelstwa, co było czynem potencjalnie autodestrukcyjnym, a w istocie zbawiennym). Następnie interpretuje teksty poetyckie, w których akcentowany jest wątek cierpienia oraz naśladowania Jezusa Chrystusa. Omówiony zostaje między innymi cykl Wiersze somatyczne, utwory oparte na symbolice korony cierniowej i śmierci na krzyżu, fragmenty dramatu Kobiety z Monte Olivetto oraz wiersz o incipicie „U szczytu antynomij....", uformowany na kształt krzyża. Badaczka poddaje je hermeneutycznej lekturze, w toku której analizuje symbole i aluzje biblijne, kojarzy literackie metafory z autobiograficznymi śladami przeżyć poety, odsłania więź między tekstami dwóch pokrewnych sobie autorów. Główną tezę szkicu stanowi twierdzenie, że w omawianej twórczości funkcjonuje nurt doloryczny - a więc taki, w którym cierpienie jest eksponowane i przedstawione jako doświadczenie etycznie wartościowe. Lektura szeregu utworów, w których rozmaicie obrazowany ból jest jednocześnie reminiscencją fizycznych i psychicznych udręk samego poety oraz nawiązaniem do Męki Pańskiej, pozwala stwierdzić, że dla autora Wierszy śródziemnomorskich cierpienie to stan duchowej przemiany, zbliżający człowieka do sfery sacrum. Autorka ostatecznie dochodzi do wniosku, że w świetle dzieła Tomasza à Kempis doloryzm Wata jawi się jako nowoczesna interpretacja idei naśladowania Chrystusa, naznaczonej koniecznością odróżnienia się od Niego.

Słowa klucze: Aleksander Wat, Tomasz à Kempis, Chrystus, cierpienie, doloryzm

\section{Abstract}

The purpose of this article is to reflect on selected works of Aleksander Watt placed in the context of De imitatione Christi by Thomas à Kempis and to verify the view that suffering functions in the consciousness and poetic imagination of the writer as a value conducive to the spiritual development of the individual. The author analyzes the poet's memoirs in order to show how reading the book he discovered during WWII, while exiled in Kazakhstan, influenced Wat's choices and attitudes, or his perception of the decisions he made (above all, the one about refusing 
to accept Soviet citizenship, which was a potentially self-destructive act, but in fact a salutary one). Then the article interprets the poetic texts that emphasize the theme of suffering and following Jesus Christ. The Wiersze somatyczne [Somatic Poems] cycle is discussed, on top of Wat's works based on the symbolism of the crown of thorns and the death on the cross, the excerpts from his drama Kobiety z Monte Olivetto [The Women of Monte Olivetto], and the poem with the incipit "U szczytu antynomij...." [At the top of antinomies...], which is formed into the shape of the cross. The researcher reads them in a hermeneutical way in the course of which she analyzes the symbols and biblical allusions, associates literary metaphors with autobiographical traces of the poet's experiences, and uncovers the connection between the texts of the two authors. The main thesis of the article is that in the discussed works, there is a dolorous theme - that is, one in which suffering is exposed and presented as an ethically valuable experience. A reading of a number of works in which pain, depicted in various ways, is at the same time a reminiscence of the poet's own physical and mental anguish and a reference to the Passion of Christ, allows one to conclude that for the author of Wiersze śródziemnomorskie [The Mediterranean Poems], suffering is a state of spiritual transformation that brings man closer to the sphere of the sacred. The author ultimately concludes that, in light of the work of Thomas à Kempis, Wat's dolorism appears as a modern interpretation of the idea of following Christ, marked by the necessity of being different from Him.

Keywords: Aleksander Wat, Tomasz à Kempis, Christ, suffering, dolorism

De imitatione Christi - datowany na średniowiecze i przypisywany Tomaszowi à Kempis poradnik życia chrześcijańskiego - to dzieło paradoksalne: bardzo skromne i niezwykle popularne, o przesłaniu w istocie ascetycznym, ale i maksymalistycznym etycznie, bezwzględnym w gloryfikowaniu ascezy, wzgardzie dla wszelkich dóbr i pokus zewnętrznych oraz wierze w najwyższą wartość duchowego bogacenia się̧. W przedmowie do polskiego wydania O naśladowaniu Chrystusa z 1989 roku Jan Twardowski pisze, że zarzucano temu utworowi między innymi „«doloryzm», nadmierną egzaltację i naiwność psychologiczną" ${ }^{3}$. Według niego nieporównanie ważniejsze są jednak te niebudzące sprzeciwu wartości - takie

3 Na temat tego utworu vide: np. Łukasz Kamykowski, „»O naśladowaniu Chrystusa« Pismo Święte w życiu duchowym", Ruch Biblijny i Liturgiczny 71/4 (2018); Andrzej Sulikowski, „»Naśladowanie Chrystusa« jako książka użytkowa”, Znak 10 (1998), https:// opoka.org.pl/biblioteka/T/TS/nasladowanie_chrystusa.html (dostęp: 30.06.2021).

4 Jan Twardowski, Przedmowa, w Tomasz à Kempis, O naśladowaniu Chrystusa, tłum. Anna Kamieńska, (Warszawa: Instytut Wydawniczy PAX, 1989), 14. Korzystam 
jak prostota tekstu, autentyczność ukazanego w nim dialogu chrześcijanina z Bogiem, inspirująca kontemplacyjność, ekumenizm - które uczyniły książkę „najbardziej rozpowszechnioną po Biblii” ${ }^{5}$, sprawiły, że była ona istotna nie tylko dla szeregu ludzi Kościoła, ale również dla pisarzy, w tym wielu polskich: Adama Mickiewicza, Juliusza Słowackiego, Cypriana Kamila Norwida, Bolesława Prusa, Stefana Żeromskiego, Władysława Reymonta, Leopolda Staffa, Juliana Tuwima, Jerzego Lieberta, a także Kazimiery Iłłakowiczówny i Anny Kamieńskiej - autorki jednego ze współczesnych przekładów De imitatione Christi ${ }^{6}$. Łączący te dwie tożsamości ksiądz-poeta zauważa:

Ciekawe, że książka $O$ naśladowaniu, choć wydaje się pod względem językowym archaiczna, bliska jest współczesnej poezji, która chce podać po prostu - niestylizowane, bez ozdobników, nagie słowo. Próby wierszowanego przekładu były chyba niezrozumieniem tego rodzaju poezji, z jakim się tu spotykamy ${ }^{7}$.

Prostolinijność przekazu, poetyckość i „nagość” słowa wywarły wrażenie na jeszcze jednym pisarzu-apologecie O naśladowaniu Chrystusa, który sam wahał się między prostotą i maksymalnym komplikowaniem tekstu, klasycyzmem i eksperymentatorstwem, bezpośredniością i ironią. Aleksander Wat - w pierwszej połowie XX stulecia czołowy polski futurysta, wprowadzający awangardę na rodzimą scenę literacką - po II wojnie światowej stał się przede wszystkim kronikarzem dramatów "swojego wieku” i poetą bólu", dokumentującym w wierszach własne fizyczne i psychiczne cierpienia, a także próby poszukiwania ukojenia w sztuce i religii. W odniesieniu do części jego twórczości użycie pojęcia doloryzmu (bez cudzysłowu, w szkicu Jana Twardowskiego sygnalizującego dystans do terminu, który nabrał cech nieledwie inwektywy,

z trzeciego wydania przekładu Anny Kamieńskiej z przedmową Jana Twardowskiego opublikowanego w Instytucie Wydawniczym PAX, pierwsze ukazało się w 1980 roku.

5 L'imitation de Jésus-Christ. Traduction nouvelle avec réflexions, trad. Georges Darboy, (Paris: Morizot, 1855), cyt. za: Twardowski, Przedmowa, 6.

6 Na temat pisarzy, którzy pozostawili świadectwo fascynacji De imitatione Christi, vide: Twardowski, Przedmowa; Anna Kamieńska, Przekładając „Naśladowanie”, w Tomasz à Kempis, O naśladowaniu Chrystusa (Warszawa: Instytut Wydawniczy PAX, 1989).

7 Twardowski, Przedmowa, 17.

8 To symptomatyczne, poświadczające status Wata jako „poety bólu”, że Krystyna Pietrych zapożyczyła z jego wiersza pierwszy człon tytułu swojej książki Co poezji po bólu? Empatyczne przestrzenie lektury, i uczyniła go jednym z głównych jej bohaterów. Vide: Krystyna Pietrych, Co poezji po bólu? Empatyczne przestrzenie lektury (Łódź: Wydawnictwo Uniwersytetu Łódzkiego, 2009). 
oznaczając przypisywane autorowi De imitatione dowartościowanie cierpiętnictwa) wydaje się zasadne 9 . Wiersze Wata o cierpieniu to utwory będące zapisem kontemplowania bólu, dociekania jego przyczyn, ale także przypisywania mu wartości w duchu chrześcijańskiego podążania śladem męki Chrystusa - nie zawsze tak ironicznego, jak mogłoby się wydawać przy pobieżnej lekturze. Dwuznaczność motywu dolorycznego odpowiada dwuznaczności, jakiej nabrała w zapiskach autora Mojego wieku zmityzowana postać Tomasza à Kempis - traktowana przez poetę jako część własnej tożsamości, a w konsekwencji zarazem przyjmowana i wypierana, gloryfikowana i lekceważona, przysparzająca nadziei i męki.

Domniemany autor O naśladowaniu Chrystusa wielokrotnie pojawia się w zapisie rozmów Wata z Czesławem Miłoszem, na kartach Dziennika bez samogłosek oraz w rozproszonych tekstach i notatkach. Aby zrekonstruować znaczenie Tomasza à Kempis dla poety, należy przywołać dwa dłuższe fragmenty jego memuarów. W pierwszym, pochodzącym $\mathrm{z}$ drugiego tomu Mojego wieku, przypomina Wat swoje - zważywszy na popularność utworu, niekoniecznie pierwsze, ale na pewno kluczowe zetknięcie się z książką, która następnie zyskała dla niego status wyroczni. Jubileuszowe londyńskie wydanie polskiego przekładu De imitatione Christi ${ }^{10}$ otrzymał on w czasie wojny, na zesłaniu w Ałma-Acie, ale, co podkreśla, nie w okresie najgorszej swojej nędzy, a już „po więzieniach, po tych szmatach"'11, kiedy czuł się raczej świadkiem niż ofiarą cierpień. Dalej wspomina:

Czułem się wcieleniem Zachodu i chrześcijaństwa. Chodziłem wśród tej barbarii, tego świata nędzy, barbarzyństwa wschodniego, wielotysiącletniego jako wcielenie, obraz, imago. Imago Zachodu, całej przeszłości Zachodu

9 Doloryzm to w ścisłym znaczeniu nurt religijnej sztuki średniowiecznej, rozwijającej się zwłaszcza w XIV i XV wieku, związany z kultem Męki Pańskiej i Matki Boskiej Bolesnej, w polskiej literaturze reprezentowany przede wszystkim przez Lament świętokrzyski. W znaczeniu szerszym to „uznawanie bólu fizycznego za przeżycie wartościowe moralnie" (vide: hasło 'doloryzm' w internetowym Słowniku języka polskiego PWN), dostrzegane w tekstach kultury różnych epok. Por. Tadeusz Sławek, „Czy ból uczy? Lekcja spojrzenia dolorycznego”, w Ból, red. Anna Czekanowicz, Stanisław Rosiek, (Gdańsk: słowo/obraz terytoria, 2004).

10 Wydanie z 1941 roku opublikowano z okazji 500-lecia domniemanego ukończenia przez Tomasza à Kempis rękopisu dzieła. Zgodnie z informacją bibliograficzną tekst przygotowano na podstawie „egzemplarza wydanego przez XX Jezuitów w Krakowie w r. 1931". Brak nazwiska tłumacza, ale przekład jest zgodny z wcześniejszym, autorstwa Henryka Jackowskiego.

11 Aleksander Wat, Mój wiek, t. II, rozmowy przeprowadził i przedmową opatrzył Czesław Miłosz, do druku przygotowała Lidia Ciołkoszowa, (Warszawa: Czytelnik, 1990), 301 [wyróżnienie - E.G.]. 
i całej przeszłości chrześcijaństwa. Byłem wtedy już bardzo syty. Głód psychiczny już znikł, mogłem już patrzeć na ludzi jedzących. Zupełnie byłem nasycony. Dokoła mnie byli głodni ludzie. [...] Widziałem ich stojących po dwadzieścia godzin po zgniłe pomidory. Byłem chrześcija n in e m. Moja jedyna książka, moja właściwa książka: Tomasz à Kempis, ten egzemplarz, to była moja właściwa książka. Dostałem w delegaturze tę książkę i wiedziałem, że to już jest moja książka, moja biblia. Ciągle ją czytałem. Nie tylko czytałem, ale była także moją wyrocznią. Zamykałem oczy, otwierałem na chybił trafił, kładłem palec na stronę i radziłem się. Zrobiłem to również w decydującej chwili, gdy się ważyło, czy mam ostatecznie wziąć ten papierek, paszport, i żyć jakoś, czy narazić siebie i rodzinę na śmierć. Otworzyłem Tomasza à Kempis i trafiłem akurat na to: „Nie wierzgaj przeciwko ościeniowi”. Wyrocznia jak wyrocznia. Czyj oścień? Stalina czy Pana Boga? Jedno i drugie. Trudno interpretować. Wtedy jednak uważałem, że Pan Bóg jest realniejszy od Stalina, i uznałem, że to znaczy: nie wierzgaj przeciwko ościeniowi Boga, że Bóg mi każe. Jednak udzielił mi się wtedy duch krucjat, może przez Tomasza à Kempis, a tu nędza, głód. Owszem, znałem to poprzednio i potem jeszcze poznałem, ale w tym czasie byłem syty i dobrze syty ${ }^{12}$.

To wyznania człowieka sytego wśród głodnych, czującego, że jest ucieleśnieniem świata chrześcijańskiego, choć nawrócił się na chrześcijaństwo niedawno - i nieostatecznie (w 1940 roku, we lwowskim więzieniu na Zamarstynowie doświadczył Wat bardzo intensywnego poczucia bycia odrzuconym przez Boga i paradoksalnej „wiary przez niewiarę”, a w kolejnym roku, w więzieniu na Łubiance przeżył mistyczną wizję swego rodzaju zetknięcia z nieskończonością, sądząc, że słyszy Pasję według św. Mateusza Bacha, co stanowiło apogeum jego rozterek religijnych i wstęp do późniejszej duchowej tułaczki na pograniczu judaizmu, chrześcijaństwa, ateizmu i agnostycyzmu $)^{14}$. Istotne, że pisarz traktuje tu

12 Odmawiając przyjęcia radzieckiego obywatelstwa w okresie przymusowej „paszportyzacji” w 1943 roku, pisarz ryzykował oskarżeniem o polski nacjonalizm i kolejnymi represjami, a wspomina wprawdzie, że podczas pobytu w Kazachstanie „był już właściwie człowiekiem sowieckim”, ale jednocześnie przeżywał swój „okres bohaterstwa”, zyskując świadomość tego, co jest dobre, a co złe. Ibidem, 307.

13 Vide: Wat, Mój wiek, t. I, 331 i nn. Por. Idem, Mój wiek, t. II, 118 i nn.

$14 \mathrm{~W}$ appendiksie do swojego pamiętnika mówionego kilkakrotnie powtarzał pisarz w odniesieniu do swoich więziennych i późniejszych przeżyć: „nie byłem nawrócony”, co stoi w sprzeczności z cytowaną tutaj w tekście głównym deklaracją „byłem chrześcijaninem", ale też pokazuje paradoksalność wiary Wata i jego poczucia przynależności religijnej - momentami odczuwanych przez niego jako pewne, ale ostatecznie zawsze ujawniających swoją nietrwałość i niepełność. Vide: Aleksander Wat, O religii: Łubianka 1941 - Italia 1957, w idem, Mój wiek, t. II, 315-324. Na temat religijności pisarza vide: 
O naśladowaniu Chrystusa nie jako zbiór pobożnych pouczeń, lecz jako źródło zaszyfrowanych wskazówek, tekst nie praktyczny, ale mistyczny. Nie wnika w treść książki, nie analizuje jej, ale przyjmuje jak słowo objawione, które inspiruje go i daje siłę do wytrwania w decyzji o odmowie przyjęcia obywatelstwa radzieckiego. Wydaje się nawet, że grzeszy tutaj naiwnością albo bezradnością: przypisując ważny życiowy wybór nie własnej woli, lecz „radzie” zaczerpniętej ze średniowiecznego przewodnika duchowego. W rozmowie z Miłoszem kreuje swój obraz sprzed lat na wizerunek neofity, rozgorączkowanego wiarą w słuszność i właściwie magiczną moc słów Tomasza à Kempis, w czym widzieć można pewną ironię, ale raczej skierowaną $\mathrm{w}$ swoim kierunku, a nie nacelowaną na tekst. Wspominając - już nie w dzienniku mówionym, ale w dzienniku intymnym - znacznie późniejsze czasy i odnosząc się do bolesnej choroby, jaka rozwinęła się u niego na początku lat 50., pisze Wat tak:

Wczoraj wziąłem drugą pigułkę koło 12 - i [...] zdałem sobie sprawę, że gwiżdżę - po raz pierwszy od tygodni, idąc szybkim lekkim krokiem jakbym miał na głowie słomkowy kapelusz 1900 i młynkował laseczką, co zawsze wprawia mnie w stan euforii. [...] Co za absurd. Ja, mistyk Hiob w sowieckiej nędzy znajdujący swe zachwycenia u Tomasza z Kempis. Ta mała książeczka w czarnej plastikowej oprawie, którą Londyn polski, ktoś chyba tam najmądrzejszy, razem ze starym obuwiem i z puszkami corned beef zaopatrzył rodaków na Syberii i którą znów wyciągnąłem z bagaży, ale na próżno otwieram na chybił trafił, szukając natchnienia, pocieszenia, rady. Ale gdy Tomasz z Kempis wyblakł, ze swoimi mistycznymi eklampis - w nędzy, w cierpieniu, w samotności, w beznadziei, z tła - z głupiego dzieciństwa, z erotycznej zawiści chłopca wobec dorosłych wesołych śpiewających modne paryskie przeboje i zawracających głowę ładnych pociągających zamożnych kuzynek - wynurza się jakby pisany sympatycznym atramentem wzór Maurice’a Chevaliera.

zwłaszcza Jarosław Borowski, „Między bluźnierca a wyznawca”. Doświadczenie sacrum w poezji Aleksandra Wata (Lublin: TN KUL, 1998); Przemysław Rojek, „Historia zamacana autobiografia”. Zagadnienie tożsamości narracyjnej w odniesieniu do powojennej liryki Aleksandra Wata (Kraków: Universitas, 2009); Tomasz Żukowski, Obrazy Chrystusa w twórczości Aleksandra Wata i Tadeusza Różewicza (Warszawa: Instytut Badań Literackich PAN, 2013); Józef Olejniczak, W-Tajemniczanie - Aleksander Wat (Katowice: Wydawnictwo Uniwersytetu Śląskiego, 1999); Anna Micińska, „»Długo broniłem się przed Tobą". Elementy do portretu Aleksandra Wata", Przeglad Powszechny 13 (1989); Andrzej Sulikowski, „Poszukiwania metafizyczne Aleksandra Wata”, Odra 9 (1992); Krzysztof Dorosz, „Umrzeć na noc. Na jedną. Do czasu... O poszukiwaniach religijnych Aleksandra Wata", Przeglad Powszechny 4 (1998); Ryszard Zajączkowski, „U źródeł refleksji religijnej Aleksandra Wata”, w $W$ „antykwariacie anielskich ekstrawagancji". O twórczości Aleksandra Wata, red. Jarosław Borowski, Władysław Panas, (Lublin: Wydawnictwo KUL, 2002). 
To daje pojęcie o głębi i absurdalności mojej animy i mojego animusa, o potędze mojego obecnego dessaroi. No, rzeczywiście, split consciousness między Tomaszem à Kempis a Mauriceem Chevalierem, którego nota bene nie cierpiałem, ba zawsze nienawidziłem, jak wszystkich aktorów estradowych. To Tomasz à Kempis we mnie nienawidził Chevaliera we mnie, i odwrotnie, Maurice Chevalier we mnie nie cierpiał mojego wewnętrznego Tomasza. Co za doborowa obskurna para więźniów, w jednej celi mojego życia, skazanych na siebie dożywotnio ${ }^{15}$.

Kreśląc antynomię między zakonnikiem-ascetą a estradowym artystą, Wat wydaje się krytyczny, a nawet lekceważący wobec „ponuraka Tomasza"16. Traktuje go jednak jako część siebie - uwewnętrzniony symbol tego, co w nim samym bolesne, ale też: święte. Wskazując na fakt, że światło objawień Tomasza à Kempis wyblakło, że już nie odnajduje w jego książce wskazówek ani pocieszenia, pisze o swoim zwątpieniu, absurdalności własnej psychiki jako pełnej sprzeczności, rozedrganej, ale także autentycznej, zbyt śmiesznej i niestabilnej, by można ją było uznać za wystylizowaną, sztuczną. Podobne skrajności ujawniają się w wyobraźni poetyckiej Wata: rozpiętej między biegunami ascezy i przepychu obrazów, udręki i euforii, powagi i groteski, kontemplowania cierpienia i uciekania od niego. Istotny jest dla tej twórczości również fakt, że teksty zawsze zawierają $\mathrm{w}$ sobie element autobiograficzny, a zarazem jakąś postać, z którą autor się utożsamia i której używa, aby w bardziej plastyczny, sugestywny sposób wyrazić własne doświadczenia i uczucia, ale też aby się od siebie zdystansować i zamącić swój zbyt wyraźny obraz w oczach czytelnika. W cytowanym fragmencie Dziennika bez samogłosek widzi i obrazuje siebie jako lawirującego między figurami Tomasza à Kempis i Maurice’a Chevaliera (a jednocześnie, co istotne, od obu tych wewnętrznych postaci się odżegnującego, szukającego prawdy o sobie jeszcze gdzie indziej). W innych fragmentach wspomnień pisarz przywołuje swoje „obroty utożsamień”, w których wcielał się w Chrystusa ${ }^{17}$.

15 Aleksander Wat, Dziennik bez samogłosek, oprac. Michalina Kmiecik, (Kraków: Wydawnictwo Uniwersytetu Jagiellońskiego, 2018), 292-293 [interpunkcja oryginalna, wyróżnienie - E.G.]. W podanym fragmencie pojawiają się znaczące słowa w obcych językach: eklampis - gr. świetlistość, rozszerzająca się jasność; dessaroi - fr. uszkodzenie, nieporządek, przemieszanie; split consciousness - ang. podzielona świadomość.

Ibidem, 293.

17 Vide: Wat, Mój wiek, t. II, 318: „Gdy utożsamiałem siebie z Jezusem na krzyżu, nie było w tym nic z zuchwalstwa, nie obniżałem Jezusa do siebie, ale siebie ceną wewnętrznej męki wywyższałem - był bowiem dla mnie tylko człowiekiem Jezusem, w nim urzeczywistniała się figuralnie dola człowieka i krzyż [...]. Obroty utożsamień na tym się nie kończyły. Byłem też, z trzema Mariami, pod krzyżem, wśród zrozpaczonych i ogarniętych paniką, i zapierających się, i wątpiących uczniów, byłem bez wątpienia Tomaszem niewiernym, któremu zmartwychwstały Chrystus nie pokazał się, nie dał 
Podobnie dzieje się w religijnych wierszach autobiograficznych, w których „ja” liryczne zarazem jest i nie jest figurą ewangelicznego Syna Człowieczego. Taki zabieg artystyczny, w zestawieniu z częstym u Wata operowaniem symboliką światła, z pewnością wolno skojarzyć z główną ideą oraz pierwszymi słowami De imitatione Christi:

Kto za mną idzie, nie chodzi w ciemności, mówi Pan. Oto są słowa Chrystusa, któremi nas upomina, abyśmy naśladowali Jego życie i obyczaje, jeśli chcemy oświecić się prawdą, a pozbyć wszelkiej ślepoty serca ${ }^{18}$.

Poszukiwanie przez Wata prawdy dokumentowane jest lirycznie między innymi w cyklu Wiersze somatyczne z 1957 roku, poświęconym cierpiącemu ciału i zbudowanym z jednej strony na wyraźnych aluzjach ewangelicznych, $z$ drugiej: na motywach autobiograficznych. $Z$ tym zbiorem utworów koresponduje nieco późniejszy wiersz bez tytułu, rozpoczynający się dystychem: „Gdy drżał w śmiertelnych potach w ogrodzie w Gethsemane, / myśmy spali. Myśmy spali, spali”19. Psychiczne cierpienie Jezusa czuwającego samotnie w Ogrodzie Oliwnym traktuje Wat jako analogiczne do późniejszej, także cielesnej męki, uznaje za oznakę konania (poty są „śmiertelne” - co jest nieco dwuznaczne: Jezus śmiertelnie się boi, już „żyje” swoją rychłą śmiercią, ale też po prostu jest człowiekiem, a więc istotą śmiertelną, która cierpi i umiera od dnia swoich narodzin, choć uświadamia sobie to dopiero w chwilach nasilonego bólu ${ }^{20}$ ). Rozwijając ten wątek w Wierszach somatycznych, używa twórca pierwszej osoby liczby pojedynczej oraz poetyki inwokacji:

Ty śpisz, a ja konam.

Wyście spali, ja konałem -

czy na cemencie bolszewickim,

czy na szpitalnym wyrku,

czy to w bistro

na rue Croulebarbe.

dotknąć ran [...]. Recytując sobie po cichu, w nocy na Łubiance: Stabat mater Dolorosa, juxta crucem lacrimosa, dum pendebat Filius, wyobrażałem sobie Olę w pozycji Marii pod krzyżem, z sercem przebitym mieczami".

18 Tomasz à Kempis, O naśladowaniu Chrystusa (Londyn: F. Mildner \& Sons, 1941$), 7$.

19 Aleksander Wat, ${ }^{* * *}$ [Gdy drżał w śmiertelnych potach...], w idem, Poezje zebrane, oprac. Anna Micińska, Jan Zieliński, (Kraków: Znak, 1992), 340. Wiersz z adnotacją „Na Wilię 1962, w Paryżu”. Kolejne cytaty poetyckie z wierszy zamieszczonych w tym tomie zbiorowym sygnuję tytułem i numerem strony w nawiasie.

20 Por. Utwór Czym jest? Czymże? (192) poświęcony agonii, która również jest częstym motywem wierszy Wata, pokrewnym motywowi cierpienia. 
Wyście spali, a ja konałem.

Tyle konań, pokonań,

odkonań, rozkonań, tyle zaklinań, rozkochań

na wolnym ogniu nie-usta-ją-ce-go

dokonywania

ciała.

[...]

Ty śpisz, a ja konam.

O, śmiertelne poty, o, czkawki,

aberracyjne widzenia,

o, truchlenia,

o, oka świdrowanie,

o, piłowanie kości, o, przypiekania

tkanek, tłuszczy,

wyszarpywania zwojów,

o, schnięcia, suchość, oschłość, schłość,

o, głos dławiony, o, język wstecz

liżący - próżno, próżno,

słońce, żegnaj niebo, żegnaj ziemio, żegnaj -

(Wiersze somatyczne, 372-374)

Cierpienia nie można adekwatnie wyrazić - język, którym się je opisuje, przypomina bełkot, oddaje rozgorączkowanie i rozpad ciała, jest fragmentaryczny, używany do zbudowania groteskowych obrazów. Podmiot liryczny tego wiersza to człowiek konający, ale zdaje się, że konający w nieskończoność, cierpiący tak bardzo, że już wyglądający śmierci, żegnający się ze światem, a jednocześnie przedłużający to pożegnanie, co akcentują powtórzenia i wyliczenia. Własną mękę i poczucie osamotnienia jednostka utożsamia z przeżyciami Jezusa, a jednocześnie, w odwrotnej perspektywie, można zobaczyć tutaj motyw Jezusa umierającego w każdym człowieku („czy na szpitalnym wyrku, / czy to w bistro...”), Jezusa, który przychodzi, choć ludzie, dopóki nie przyjdzie im samym cierpieć i umierać, są obojętni wobec jego cierpienia i śmierci, pogrążeni w metaforycznym śnie. Wydaje się pobrzmiewać w tym utworze pewne przesłanie etyczne - dowartościowanie bólu jako przeżycia zbliżającego do Boga (w Inwokacji napisze Wat: „Jezus jest twoim Bogiem / cierpiące ludzkie ciało", 351) i przypominającego o człowieczeństwie jako zdolności do współczucia, utożsamienia się z cudzym cierpieniem. Na płaszczyźnie religijnej można zaś zobaczyć w tym ślad hasła: „Cierp z Chrystusem i dla Chrystusa, jeśli chcesz królować z Chrystusem”21.

21 Tomasz à Kempis, O naśladowaniu Chrystusa, 86. 
Chrystus królujący - i na drodze do Królestwa Bożego cierpiący w koronie cierniowej - jest nieobecnym i nieodzownym bohaterem kilku innych wierszy w bardzo niejasny, choć wyraźny sposób odwołujących się do Ewangelii. Jeden z nich brzmi tak:

Skoro wiesz, że tobie przeznaczone,

przyjm te trzy korony.

Żelazna parzy czoło. Po niej ołowiana

jątrzy ranę.

Tamte znasz. Na sam ostatek

zostaw nową,

cierniową.

$\left({ }^{* *}[\right.$ Skoro wiesz, że tobie przeznaczone...], 311)

Ta liryczna miniatura przesycona jest przekonaniem o konieczności cierpienia. Podmiot liryczny zwraca się do adresata, przekonując jedynie o tym, że skoro i tak nie można odmówić, należy przyjąć (z godnością, z ufnością?) „trzy korony” przysparzające bólu. Korona cierniowa jest „nowa” i ostatnia - być może symbolizując ostateczny, najwyższy triumf ducha, ale to pozostaje niejasne, podobnie jak pozostawiona interpretacyjnej wynalazczości czytelnika tożsamość „ty” lirycznego. W myśl niniejszej koncepcji odczytania tej poezji jest nim człowiek utożsamiający się z Jezusem, kroczący w stronę chrześcijaństwa, ale jeszcze niepewny wiary - i tym mniej jej pewny, że czuje, jakby był na nią skazany, zmuszony przez cierpienie do desperackiej ucieczki w religię czyniącą cierpienie wartością, a przez to tak naprawdę pozbawiony wolnej woli. Podobna myśl kryje się w wierszu uznawanym powszechnie za najwięcej mówiący o religijnych poszukiwaniach Wata. To ukończony w 1943 roku utwór o incipicie: „Długo broniłem się przed Tobą ”22, w którym podmiot

22 Na temat tego wiersza vide: zwłaszcza Kazimierz Brakoniecki, „Światłość w ciemności. O wierszach Aleksandra Wata”, Poezja 10 (1982): 18-19; Marek Walczak, „»Uciekałem przed Tobą w popłochu «. Lieberta i Wata poetyckie świadectwa dialogu z Nieskończonym", Polonistyka 7/8 (1992); Józef Olejniczak, W-Tajemniczanie..., 120-123; Tomasz Żukowski, Obrazy Chrystusa..., 85-87. Obraz nieokreślonej siły, która przemocą przejmuje władzę nad podmiotem, pojawia się także w innym wierszu dotykającym tematu cierpienia, rozpoczynającym się słowami: „Tej znów nocy, dobrze po północy, / przyszedł do mnie P.B.” - a kończącym: „Nie krzyczałem, choć bolało. / Wiadomo: co czyni, czyni z miłości dla mnie" (337). I znów obecne są tutaj bardzo wyraźne, choć niedopowiedziane aluzje religijne: „P.B.” to być może Pan Bóg, a być może hiperbolizowany, upostaciowiony Pan Ból; cierpienie jest przedstawione dwuznacznie: ból jest źródłem wiary, ale też niewykluczone, że wiara jest źródłem bólu, bo Bóg zsyła mękę, aby zmusić człowieka do uległości. 
liryczny ucieka od prześladującej go przemożnej siły, ale w końcu ulega przemocy. W tekście pojawia się wizja ukrzyżowania, nie całkiem zgodna z biblijnym wzorem:

Gdy mnie dopadłeś i znienacka na pal mnie wbiłeś!

Między łotrami mnie powiesiłeś!

Potem wbijałeś mi gwoździe w czoło w ręce i nogi!

Bok mi przebiłeś włócznią odjętą żołnierzowi!

I napoiłeś mnie piołunem i octem!

Gdy napisałeś: król żydowski, to z głowy zdjąłeś koronę $\mathrm{z}$ cierni i rozkrwawiłeś moje czoło.

Noc wtedy była, trzęsienie ziemi.

Wtedy przejrzałem wtedy poznałem Eli krzyknąłem lamma sabahtani. $(* * * 262-263)$

Narzucający się nam obraz ukrzyżowania jest tutaj pozbawiony elementu najważniejszego - krzyża, choć pojawiają się wszystkie inne kluczowe atrybuty Męki Pańskiej: korona cierniowa, bok przebity włócznią, gwoździe w ciele, szyderczy napis „król żydowski”, cierpki napój... Zapada ciemność - i w tej ciemności rozbrzmiewa krzyk „Eli lamma sabahtani”. Podmiot niemal całkowicie utożsamia się z Chrystusem, ale wyraźnie sygnalizuje niepełność tego zjednoczenia. Autor być może wskazuje w ten sposób na niedoskonałość człowieka, który powinien dążyć do naśladowania Chrystusa, pamiętając o tym, że to wysiłek niemający końca, możliwy jedynie w ludzkim wymiarze. Gest odróżnienia się jest sygnałem pokory i świadomości, a więc dążenia do Prawdy, która znajduje się poza granicą poznania. Być może zaś Wat pisze w ten sposób, odwołując się do ściśle osobistych przeżyć, ponieważ czuje, że sam nie ma wyboru. Chory, a zatem skazany na cierpienie, nie może dobrowolnie wstąpić na ścieżkę, którą Tomasz à Kempis i inni mistycy, ale także 
fenomenolog Max Scheler, nazywają królewską drogą Krzyża Świętego ${ }^{23}$. W tak zatytułowanym rozdziale O naśladowaniu Chrystusa autor pisze, wyjątkowo w tonie przygany:

Jakżeż ty śmiesz szukać innej drogi, poza tą królewską drogą, drogą Krzyża Świętego? [...] Błądzisz, błądzisz, jeśli szukasz czego innego, prócz cierpień: albowiem cały ten żywot śmiertelny pełen jest nędzy i zewsząd naznaczony krzyżami. [...] Kiedy już dojdziesz do tego, że utrapienie stanie ci się słodkiem i polubisz je dla Chrystusa: wtedy bądź pewny, że dobrze dzieje się z tobą, bo raj na ziemi znalazłeś ${ }^{4}$.

Szukanie cierpień - jego sens, możliwość i własna dla takiej praktyki predylekcja - jest dla Wata kolejną kwestią do rozważenia, a nie przyjęcia na wiarę. $\mathrm{W}$ jednym $\mathrm{z}$ narracyjnych wierszy $\mathrm{z}$ ineditów opisuje spotkanie z lekarzem - ironicznie skrupulatny opis początku tej historii przeradza się następnie w refleksję na temat własnej, niejednoznacznej, relacji z bólem:

Mądry neurolog z San Francisco

powiedział: „Te bóle, sam pan wie,

są nieuleczalne... Morfina? Niekiedy pomaga.

Na krótko. Krótko. Stanowczo odradzam".

I wpatrzywszy się we mnie przez okulary,

które dotąd siedziały w spokoju rozkraczone

na ładnym rustykalnym sprzęcie,

nader wypukłe szkła w rogowej oprawie:

„Czy ty sam nie szukałeś ich? Zawsze? Od zawsze?

Przypomnij sobie! A filozofię jaką ty miałeś?

Od dawna! Od dziecka”

Ja?!

który zawsze pragnąłem orgazmu, wiekuistego?!

który szczęścia łaknąłem jak kania dżdżu?!

który wyssałem radość z nieba, z każdego nieba,

23 Henryk Suzo twierdzi, że „Droga do Boga przez Chrystusa cierpiącego to via regia, droga królewska”. Cyt. za: Wiesław Szymona, Wprowadzenie, w Jan Tauler, Mistrz Eckhart, Henryk Suzo, Ścieżka do Boga. Wybór pism, tłum. i oprac. Wiesław Szymona, (Poznań: W drodze, 1996), 12. Max Scheler drogę błogiego cierpienia i dokonującego się w cierpieniu wyzwolenia od niego, dzięki miłosiernej miłości Boga, nazywa „Królewską Drogą Krzyża”. Cyt. za: Włodzimierz Wilowski, Metafizyka cierpienia. Od Arystotelesa, poprzez myśl indyjską, do myśli chrześcijańskiej (Poznań: Wydawnictwo Naukowe Instytutu Filozofii UAM, 2010), 42-43.

24 Tomasz à Kempis, O naśladowaniu Chrystusa, 120-123. 
i blaski z ziemi, z wszelakiej ziemi, gąbka chciwa?!

który włóczyłem się od Edenu do Cytery, od Hesperyd do Arabii Felix, wte i wewte?!

Ja?! Przenikliwy był ten doktór Schiller z San Francisco.

$(* * * 409-410)$

Postać lekarza, doradzającego pacjentowi zanurzenie się w bólu i sugerującego, że ten w istocie zawsze pragnął cierpienia, właśnie: „szukał” go, jest kolejną w tej poezji nieoczywistą figurą Boga - odsłaniającego przed podmiotem prawdę, obdarzającego go łaską poznania oraz darem cierpień, które okazują się mieć głębszy sens. Bo jedynie powierzchownie kpi tutaj Wat z samego siebie jako zdemaskowanego masochisty albo rozpacza nad niemożliwością spełnienia dziecięcych marzeń o bezbolesnym życiu. Kryje się w tym, poetycko opracowana w żartobliwej manierze, myśl o odnalezieniu radości w cierpieniu, do którego zostało się i tak przeznaczonym, o pogodzeniu się z nim, a więc jednak: w yb or ze drogi bolesnej, bo - o czym przypomina Dietrich Bonhoeffer - „Naśladowanie to passio passiva, to konieczność cierpienia"25.

Tezę Tomasza, że „cały ten żywot śmiertelny pełen jest nędzy i zewsząd naznaczony krzyżami”26 autor Ciemnego świecidła wprowadza wprost w życie w uniwersum swojej poezji, w której nie tylko przewija się ciągle motyw cierpienia, ale także wyrastają zewsząd znaki krzyża. Co istotne, podobnie jak inne symbole świętości, krzyż ten jest zawsze zniekształcony, wybrakowany albo strywializowany, pokazany w formie tandetnej, groteskowej - co służy w poezji Wata zaakcentowaniu dystansu pomiędzy tym, co boskie, a tym, co ludzkie. Naśladowanie przez człowieka Chrystusa, aby było wierne i autentyczne, musi być demonstracyjnie nie-boskie, zwyczajne, na różne sposoby umniejszane, bowiem świętość należy ukryć pod pozorami niedoskonałości i znikomości. Nawet najpiękniejszymi i najbardziej wyrafinowanymi kształtami doczesnej materii, przełożonymi na ludzką wyobraźnię, należy wzgardzić i odrzucić je, ponieważ nie są one w stanie posłużyć za środek do wyrażenia Prawdy. Wyrazić ją mogą, przez zaprzeczenie, tylko rzeczy pozornie godne jedynie pogardy. Dlatego świętą księgą, „biblią” staje się O naśladowaniu Chrystusa - mała

25 Dietrich Bonhoeffer, Naśladowanie, tłum. Joanna Kubaszczyk, (Poznań: W drodze, 1997), 51.

26 Por. przypis nr 24. 
czarna książeczka oprawiona w ceratę, zaś krzyżem, który przynosi wiarę, „krzyżyk mały, bakelitowy, ciemnobrązowy z tychże darów”27.

W jedynym napisanym przez Wata dramacie, zatytułowanym Kobiety $z$ Monte Olivetto, wątek Męki Pańskiej umieszczony zostaje w kontekście Zagłady. Pojawia się tam „Ewangelia według św. Mateusza” napisana jako balet („Taneczna Golgota [...]. Straszliwa tajemnica ludzkości jako feeria!"28), w którym w główną rolę wcielić się miała kobieta, tancerka o „twarzy Chrystusa, ze znanego rysunku Leonarda...”29 - zgładzona w Holokauście żona jednego z bohaterów. To również wyraźny i, by tak rzec, wielowymiarowy ślad De imitatione Christi, ponieważ nie tylko jedna z postaci pokazana została jako wcielenie (czy też: subwersywna imitacja) Chrystusa, ale „znany rysunek Leonarda” to najpewniej zamieszczona w londyńskim wydaniu $O$ naśladowaniu czarno-biała, niewyraźna reprodukcja Głowy Chrystusa da Vinciego, tam podpisana jako „Najświętsze Oblicze Zbawiciela”. W dramacie pojawia się także opis innego związanego z ukrzyżowaniem dzieła sztuki:

W Uffizi wisi obraz Filipina Lippi i Perugina: dwie drabinki przy krzyżu, Józef z Arymatei i dwaj uczniowie zdejmują ciało Chrystusowe. [...] Przed chwilą, a może przed wiecznością, dokonało się. A teraz jest cisza, przebaczenie, uspokojenie, które spływa na uczniów, na obie Marie u dołu, na ziemię w promiennych różach, w serdecznych czerwieniach, w oczarowanych fioletach, w drżących zieleniach - a z Męki zostały tylko trzy ćwieki na czerwonym płaszczu na dole ${ }^{30}$.

Mimo dominującego na obrazie i w jego opisie spokoju, pozostał na nim znak męki - w postaci materialnego drobiazgu, „tylko trzech ćwieków" lekko zaburzających harmonię. Bez nich przedstawiony w dziele krzyż, monumentalny, otoczony wyidealizowanymi postaciami z zachowaniem dbałości o symetrię kompozycji, byłby zbyt doskonały, nie-ludzki. Ten miniaturowy graficzny znak, wyeksponowany w tekście wytrąca z tego wrażenia. Krzyż musi zawierać w sobie skazę, musi być „skrzywionym krzyżem" (Kołysanka dla konającego, 181). Wśród utworów odnalezionych po śmierci poety znajduje się carmen figuratum, niepublikowany

27 Aleksander Wat, Omarchadżew, w idem, Bezrobotny Lucyfer i inne opowieści, red. Włodzimierz Bolecki, Jan Zieliński, (Warszawa: Czytelnik, 1993), 198.

28 Aleksander Wat, Kobiety z Monte Olivetto, oprac. Jan Zieliński, (Warszawa: Biblioteka Narodowa, 2000), 46.

29 Ibidem.

30 Ibidem, 45-46 [wyróżnienie - E.G.]. 
$\mathrm{w}$ tomie poezji zebranych wiersz, którego pierwszą wersję zapisał Wat na opakowaniu leków przeciwbólowych. Tekst ukształtowany został jako zdeformowany krzyż:

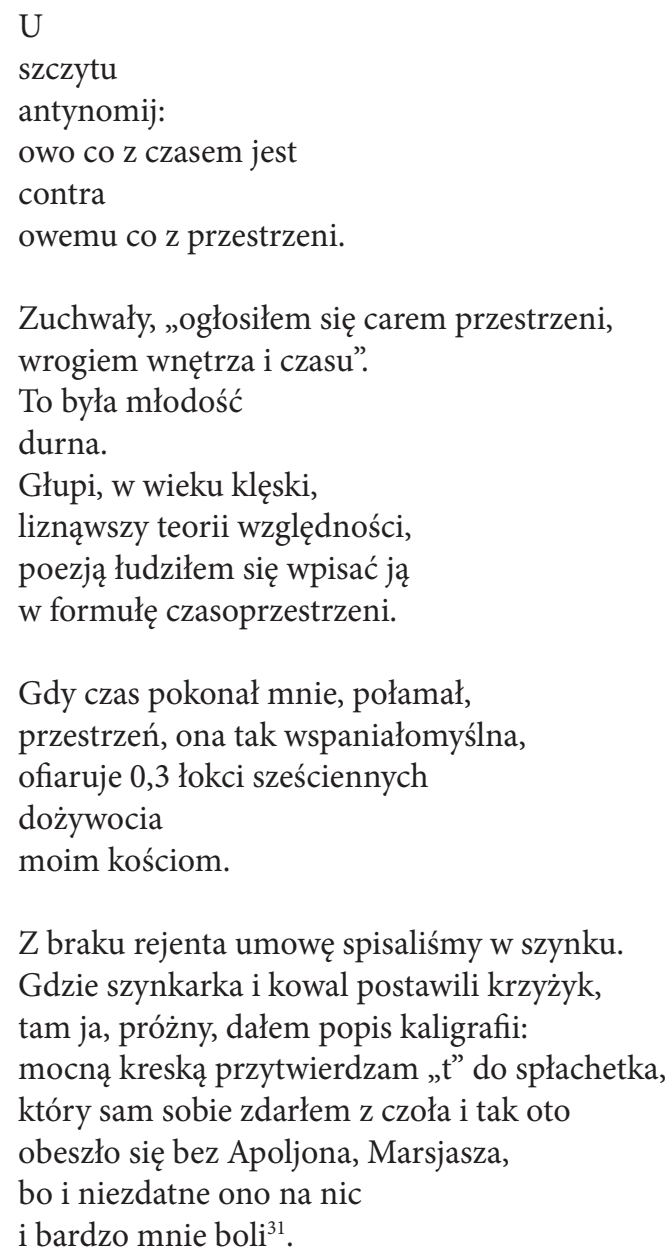

Gdy czas pokonał mnie, połamał, przestrzeń, ona tak wspaniałomyślna, ofiaruje 0,3 łokci sześciennych dożywocia moim kościom.

Z braku rejenta umowę spisaliśmy w szynku.

Gdzie szynkarka i kowal postawili krzyżyk, tam ja, próżny, dałem popis kaligrafii:

mocną kreską przytwierdzam „t" do spłachetka, który sam sobie zdarłem z czoła i tak oto obeszło się bez Apoljona, Marsjasza, bo i niezdatne ono na nic i bardzo mnie boli ${ }^{31}$.

W ostatniej strofoidzie w roli krzyża występuje litera „"t" z nazwiska Wata, zwykły znak graficzny zamieniony w niezwykły symbol. Znacząca jest historia jego kolejnych wersji. W pierwszym odręcznym zapisie, zanotowanym przez poetę z widocznym pośpiechem, pojawia się znak krzyża uproszczony do postaci dwóch przecinających się linii - a więc

31 Aleksander Wat, ${ }^{* * *}$ [U szczytu antynomij...], oprac. Adam Dziadek, Zeszyty Literackie 108 (2009): 7-8. 
odległa od doskonałości, ale jednak imitacja symetrycznego wzorca. W drugim rękopisie autor umieścił w cudzysłowie zwykłą, nieco tylko wyróżnioną graficznie literę „t”. W maszynopisie narysował natomiast ręcznie lekko pochylony krzyżyk, z podstawą zniekształcaną przez trzy skierowane w prawą stronę kreski („trzy ćwieki na znak męki”), których główną funkcją jest zaznaczenie nadmiaru i deformacji, analogicznie do kształtu całego tekstu - czego nie można powielić w druku' ${ }^{32}$. Podpisanie się krzyżykiem to pusta sygnatura, naśladowanie analfabetyzmu, jakby poeta próbował zapomnieć o piśmie, porozumiewać się znakami - zrozumiałymi dla wszystkich, wspólnymi. Jest to jednak także maksymalnie skoncentrowany symbol, odwołujący się do męki i śmierci Chrystusa, wszystkiego, co związane z chrześcijaństwem i wiarą, a także do fizycznych i duchowych cierpień poety. Wizerunki krzyża: kontur tekstu, słowo „krzyżyk” i litera „t” nakładają się na siebie, nawarstwiają - wszystkie odróżnione od krzyża prototypowego.

W wierszu o incipicie „U szczytu antynomij...” istotny jest także obraz samookaleczenia - podpis krzyżykiem zostaje złożony na „spłachetku” skóry zdartej z czoła. To niejedyna w tej poezji autoironiczna wizja samoukrzyżowania: ofiary szyderczej, maskaradowej, bluźnierczego rytuału, który zdaje się wyrazem przekonania, że ludzka ofiara jest i tak mimowolna, daremna, a przypisywanie jej sensu to gest rozpaczy. W Odjeździe Anteusza czytamy:

Sosna w Otwocku, w liszajach, w szronie, w próchnicy; okaleczała, z nią utożsamiłem się rozkrzyżowawszy się na niej szyderczo, pewnej marcowej nocy roku 1939.

(Odjazd Anteusza; CŚ, PZ 330)

W dedykowanym Antoniemu Słonimskiemu Pejzażyku 1939:

Sosna,

niska, ale rozłożysta. Pięknaś, córo Saronu Hiperborejów! Udręczone kikuty

32 Trzy wersje utworu analizuje Mateusz Antoniuk, który zamieszcza w swoim artykule fotografie rękopisów i maszynopisu wiersza. Vide: Mateusz Antoniuk, „Jak czytać stronę brulionu. Krytyka genetyczna i materialność tekstu”, Wielogłos 1/31 (2017). Piotr Bogalecki w „literze-krzyżyku” dostrzega także hebrajską literę ת [taw] - „święte znamię umieszczane na czołach wybranych i wybawionych". Vide: Piotr Bogalecki, „»Usługi bezimienne«: figura marana w twórczości Aleksandra Wata”, Pamiętnik Literacki 110/4 (2019): 105. 
już nie wołają do nieba. Nawet o pomstę nie.

Liszaje. Grzybnie. Mchy. Łzawe storczyki. Gniazda larw.

Ukrzyżowałem się na niej. Przez smutne szaleństwo.

I oboje, unisono, dwoje żebraków, jeden proszalny,

drugi gniewny, ale syjamskie rodzeństwo, intonujemy

szpetnymi głosami naszymi o zmiłowanie. Robaki obgryzają nas

u korzonków, śnieżek nas siecze parzący, a to są wróżby moje

na rok bieżący, 1939, i wszystkie dalsze.

(Pejzażyk 1939; CŚ, PZ 332)

Utożsamienie się z umierającym Chrystusem ma takie samo znaczenie, jak utożsamienie się z niszczejącym drzewem, skazanym na spróchnienie - w którego kształcie zobaczyć można wszystko (symbol ciała, krzyża, sylwetkę człowieka modlącego się albo wygrażającego niebu) i każde ze znaczeń będzie równie niepewne. To rozpraszanie sensów staje się w istocie ich namnażaniem i wzmacnianiem. Jeśli prawdą jest, że transcendencja bytu człowieka dokonuje się przez cierpienie albo przez ucieczkę od niego, to w poezji Aleksandra Wata te dwa stany nieustannie przesilają się ze sobą, a tym samym współistnieją. W wierszach dolorycznych autora Ciemnego świecidła zdają się pobrzmiewać echa głęboko przeżytej lektury De imitatione Christi - przez różnorodne symbole, obrazy i ekspresje bólu, ironizowane, uniezwyklane, przesycone pogardą dla rzeczy doczesnych i pokorą wobec Nieznanego, przeziera wiara w nie tylko etyczną, ale i metafizyczną wartość cierpienia, wypracowywana na drodze ciągłej wewnętrznej walki, przekraczania siebie.

\section{Bibliografia}

\section{Książki i monografie}

Bonhoeffer Dietrich, Naśladowanie, tłum. Joanna Kubaszczyk, (Poznań: W drodze, 1997).

Borowski Jarosław, „Między bluźniercą a wyznawca”. Doświadczenie sacrum w poezji Aleksandra Wata (Lublin: TN KUL, 1998).

Kamieńska Anna, Przekładając „Naśladowanie”, w Tomasz à Kempis, O naśladowaniu Chrystusa, tłum. Anna Kamieńska, (Warszawa: Instytut Wydawniczy PAX, 1989).

Olejniczak Józef, W-Tajemniczanie - Aleksander Wat (Katowice: Wydawnictwo Uniwersytetu Śląskiego, 1999).

Pietrych Krystyna, Co poezji po bólu? Empatyczne przestrzenie lektury (Łódź: Wydawnictwo Uniwersytetu Łódzkiego, 2009). 
Rojek Przemysław, „Historia zamącana autobiografia”. Zagadnienie tożsamości narracyjnej w odniesieniu do powojennej liryki Aleksandra Wata (Kraków: Universitas, 2009).

Sławek Tadeusz, Czy ból uczy? Lekcja spojrzenia dolorycznego, w Ból, red. Anna Czekanowicz, Stanisław Rosiek, (Gdańsk: słowo/obraz terytoria, 2004).

Szymona Wiesław, Wprowadzenie, w Jan Tauler, Mistrz Eckhart, Henryk Suzo, Ścieżka do Boga. Wybór pism (Poznań: W drodze, 1996).

Tomasz à Kempis, O naśladowaniu Chrystusa (Londyn: F. Mildner \& Sons, 1941).

Twardowski Jan, Przedmowa, w Tomasz à Kempis, O naśladowaniu Chrystusa, tłum. Anna Kamieńska, (Warszawa: Instytut Wydawniczy PAX, 1989).

Wat Aleksander, ${ }^{* * *}$ [U szczytu antynomij...], oprac. Adam Dziadek, Zeszyty Literackie 108 (2009): 7-8.

Wat Aleksander, Coś niecoś o „Piecyku”, w idem, Notatniki, oprac. Adam Dziadek, Jan Zieliński, (Katowice: Instytut Badań Literackich PAN, 2015).

Wat Aleksander, Dziennik bez samogłosek, oprac. Michalina Kmiecik, (Kraków: Wydawnictwo Uniwersytetu Jagiellońskiego, 2018).

Wat Aleksander, Kobiety $z$ Monte Olivetto, oprac. Jan Zieliński, (Warszawa: Biblioteka Narodowa, 2000).

Wat Aleksander, Moralia, w idem, Dziennik bez samogłosek, (Warszawa: Czytelnik, 1990).

Wat Aleksander, Mój wiek, t. I-II, rozmowy przeprowadził i przedmową opatrzył Czesław Miłosz, do druku przygotowała Lidia Ciołkoszowa, (Warszawa: Czytelnik, 1990).

Wat Aleksander, Omarchadżew, w idem, Bezrobotny Lucyfer i inne opowieści, red. Włodzimierz Bolecki, Jan Zieliński, (Warszawa: Czytelnik, 1993).

Wat Aleksander, Poezje zebrane, oprac. Anna Micińska, Jan Zieliński, (Kraków: Znak, 1992).

Wilowski Włodzimierz, Metafizyka cierpienia. Od Arystotelesa, poprzez myśl indyjską, do myśli chrześcijańskiej (Poznań: Wydawnictwo Naukowe Instytutu Filozofii UAM, 2010).

Zajączkowski Ryszard, U źródeł refleksji religijnej Aleksandra Wata, w W „antykwariacie anielskich ekstrawagancji". O twórczości Aleksandra Wata, red. Jarosław Borowski, Władysław Panas, (Lublin: Wydawnictwo KUL, 2002).

Żukowski Tomasz, Obrazy Chrystusa w twórczości Aleksandra Wata i Tadeusza Różewicza (Warszawa: Instytut Badań Literackich PAN, 2013).

\section{Czasopisma}

Antoniuk Mateusz, „Jak czytać stronę brulionu. Krytyka genetyczna i materialność tekstu", Wielogłos 1/31 (2017): 39-66.

Bogalecki Piotr, „»Usługi bezimienne «: figura marana w twórczości Aleksandra Wata", Pamiętnik Literacki 110/4 (2019): 79-107.

Brakoniecki Kazimierz, „Światłość w ciemności. O wierszach Aleksandra Wata”, Poezja 10 (1982): 6-22. 
Dorosz Krzysztof, „Umrzeć na noc. Na jedną. Do czasu... O poszukiwaniach religijnych Aleksandra Wata", Przeglad Powszechny 4 (1998): 72-83.

Kamykowski Łukasz, „»O naśladowaniu Chrystusa « - Pismo Święte w życiu duchowym", Ruch Biblijny i Liturgiczny 71 (2018): 305-319.

Micińska Anna, „»Długo broniłem się przed Tobą«. Elementy do portretu Aleksandra Wata", Przegląd Powszechny 13 (1989): 395-408.

Sulikowski Andrzej, „»Naśladowanie Chrystusa « jako książka użytkowa”, Znak 10 (1998), https://opoka.org.pl/biblioteka/T/TS/nasladowanie_chrystusa. html [dostęp: 30.06.2021).

Sulikowski Andrzej, „Poszukiwania metafizyczne Aleksandra Wata”, Odra 9 (1992): 44-51.

Walczak Marek, „»Uciekałem przed Tobą w popłochu«. Lieberta i Wata poetyckie świadectwa dialogu z Nieskończonym”, Polonistyka 7/8 (1992): 430-437. 